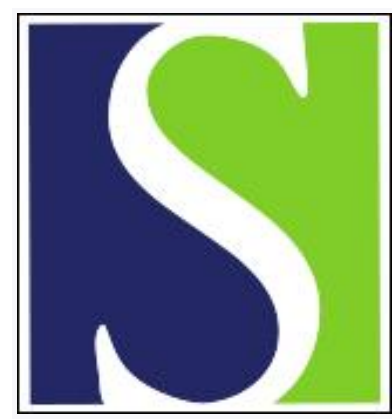

Scand J Work Environ Health 2007;33(2):114-122

https://doi.org/10.5271/sjweh.1114

Issue date: 31 Apr 2007

Exposure, lung function decline and systemic inflammatory response in asphalt workers

by Ulvestad B, Randem BG, Hetland S, Sigurdardottir G, Johannessen E, Lyberg T

Affiliation: Mesta AS, PO Box 5133, N-1503 Moss, Norway. bente.ulvestad@mesta.no

Refers to the following text of the Journal: 2001;27(4):250-257

Key terms: asphalt worker; exposure; interleukin-6; lung function decline; oil mist; systemic inflammatory response

This article in PubMed: www.ncbi.nlm.nih.gov/pubmed/17460799

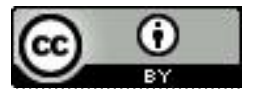




\title{
Exposure, lung function decline and systemic inflammatory response in asphalt workers
}

\author{
by Bente Ulvestad, PhD, ${ }^{1}$ Britt Grethe Randem, PhD, ${ }^{2}$ Siri Hetland, MSc, ${ }^{3}$ Gudmunda Sigurdardottir, RN, ${ }^{1}$ \\ Egil Johannessen, RN, ${ }^{1}$ Torstein Lyberg, PhD ${ }^{4}$
}

Ulvestad B, Randem BG, Hetland S, Sigurdardottir G, Johannessen E, Lyberg T. Exposure, lung function decline and systemic inflammatory response in asphalt workers. Scand Work Environment Health 2007;33(2):114-121.

\begin{abstract}
Objectives The aim of this study was to determine the association between exposures in asphalt work and changes in lung function, blood concentrations of interleukin-6 (IL-6), micro-C-reactive protein, and fibrinogen among asphalt workers during a work season.

Methods Blood samples from all asphalt workers $(\mathrm{N}=140)$ in Norway's largest road construction and maintenance company were taken in April-May 2005 and again in September-October 2005. Spirometric tests of the asphalt workers and a reference group (heavy construction workers, $\mathrm{N}=126$ ) were carried out before the asphalt season, and the asphalt workers were tested again at the end of the season. Exposure to total dust, oil mist, polycyclic aromatic hydrocarbons, and gases was measured by personal samplers during the asphalt season.

Results The asphalt workers had a significantly a lower forced expiratory volume in 1 second $\left(\mathrm{FEV}_{1}\right)$ and forced expiratory flow rate of $50 \%$ of the forced vital capacity than the reference group at the beginning of the season. The asphalt workers were divided according to their exposure into two groups, asphalt pavers $(\mathrm{N}=81)$ and asphalt plant operators and truck drivers $(\mathrm{N}=54)$. The screedmen, a group of the asphalt pavers, had a statistically significant lower $\mathrm{FVC}$ and $\mathrm{FEV}_{1}$ after one season of asphalt work than all of the other asphalt workers $(\mathrm{P}<0.05)$. The mean plasma concentration of IL- 6 increased among the asphalt pavers from $1.55 \mathrm{pg} / \mathrm{ml}$ before the season to $2.67 \mathrm{pg} / \mathrm{ml}$ at the season's end ( $\mathrm{P}=0.04$, adjusted for current smoking).
\end{abstract}

Conclusions Exposure in asphalt paving may enhance the risk of lung function decline.

Key terms interleukin-6, oil mist.

Asphalt paving is used for road construction and road maintenance and is carried out all over the world. In Norway, 5 million tons of asphalt is laid every year, and about 3000 workers are involved in the production and application of various asphalt mixes. The asphalt season in Norway is short, lasting from April to October in most of the country.

Air pollution is a public health issue that constitutes a health problem for workers in the heavy construction industry and is also a problem for workers involved in asphalt paving. Air pollution may affect lung function and has also been shown to affect the immune system (1-4). Asphalt workers are exposed to bitumen fumes, oil mist and vapor, polycyclic aromatic hydrocarbons (PAH), and vehicle exhaust (nitrogen dioxide, carbon monoxide) (5). Studies have reported increased mortality from respiratory diseases among asphalt workers. A standardized mortality ratio (SMR) of 207 [95\% confidence interval (95\% CI) 95-393] for bronchitis, asthma, and emphysema was reported in 1991 for mastic asphalt workers (6). The asphalt worker mortality study involving 29820 European asphalt workers reported that, relative to construction workers, asphalt workers had a risk ratio (RR) of 1.36 (95\% CI 1.06-1.74) of dying from a nonmalignant respiratory disease (7). Cross-sectional studies have shown a greater risk for respiratory symptoms among asphalt workers than for road maintenance workers (8). Adverse respiratory effects and systemic inflammatory responses in workers exposed to dusts and fumes have recently been reported for several different occupations, for example, welders (9), firefighters (10, 11) salt miners (12), and tunnel workers (13-15).

In an earlier cross-sectional survey, we found that asphalt workers had more respiratory symptoms and

1 Department of Occupational Medicine, Mesta AS, Moss, Norway.

2 Department of Occupational Medicine, Ulleval University Hospital, Oslo, Norway.

3 Eurofins Norway, Bryn, Oslo, Norway.

4 Center for Clinical Research, Ulleval University Hospital, Oslo, Norway.

Requests for reprints to: Dr B Ulvestad, Mesta AS, PO Box 5133, N-1503 Moss, Norway. [E-mail: bente.ulvestad@mesta.no] 
airflow limitation than heavy construction workers (16). However, exposure measurements were not carried out, and we were not able to point out which exposures or worktasks were of importance. Neither did we investigate signs of systemic inflammation. Our present report presents the results of a parallel and larger cohort. We hypothesized (i) that workers exposed to air pollutants during asphalt work would have a higher risk of accelerated decline in lung function than other road construction workers, (ii) that exposure to bitumen fumes would be associated with signs of inflammation as indicated by inflammatory markers, and (iii) that these findings would be related to job tasks and differences in exposure to particles or gases during the asphalt season. We also hypothesized that smoking status would modify the association (17).

\section{Study population and methods}

\section{Study population}

All of the asphalt workers (paver operators, screedmen, roller drivers, asphalt strippers, asphalt plant operators, and asphalt lorry drivers) ( $\mathrm{N}=140$ males) employed in Norway's largest road construction and road maintenance company were studied with lung function tests and blood samples in April-May 2005, before the asphalt season started. As a reference group, 126 male nonasphalt heavy construction workers, mainly machine operators (hereafter referred to as the reference group) belonging to the same company were included in the before-season lung function study. Because of economic constraints, we did not collect blood samples from the reference group. Demographic data on the study participants are given in table 1.

The group of asphalt workers was studied again with lung function tests and blood samples just before the asphalt season ended, September-October 2005. The asphalt workers were divided according to their exposure into two groups, asphalt pavers (paver operator, screedman, roller driver, and asphalt stripper) $(\mathrm{N}=81)$ and asphalt plant operators and asphalt truck drivers $(\mathrm{N}=54)$, who then served as an internal comparison group for changes in the inflammatory markers. The study was approved by the National Data Inspectorate and the Regional Medical Board of Ethics.

\section{Description of asphalt work}

Asphalt consists of bitumen, as a binder, mixed with crushed stone. In road paving the bitumen content is usually $4-5 \%$. Bitumen is the residue of the distillation of selected petroleum crude oils. The type of bitumen and the size of the gravel vary with the properties requested for the road surface. Filler or fibers can also be added to modify the properties of the asphalt, and small amounts of aliphatic amines are used to improve the binding between the bitumen and the stone material.

Asphalt is produced by heating and drying the gravel and mixing the hot bitumen with it. The asphalt is transported to the paving site by trucks and emptied onto the front of the paving machine. It passes underneath the machine and is spread to the desired width by the screed. Two screedmen control the asphalt discharge through the screed, and they fix the edges of the asphalt on the road manually. Subsequently, a roller compresses the asphalt.

\section{Exposure assessment}

Sampling strategy. Measurements were carried out between April and October 2005 to assess exposure in modern asphalt work. A random sample of workers representing different worktasks was asked to participate in the exposure assessment. Participation was voluntary, but all of the selected workers decided to participate.

Exposure to dust and gases was determined by means of personal sampling, and two or more agents were measured simultaneously for each person for at least 2 days. The sampling duration was $7-8$ hours because of the limited battery capacity of the sampling equipment. The sampling time was considered representative for the whole workshift because the same tasks were repeated all the time.

Sampling methods and analyses. Total dust and particulate PAH were collected on glass fiber filters (Whatman International Ltd, Maistone, UK), fitted in 37-mm closed-faced aerosol filter cassettes (Millipore Corporation, Bedford, MA, USA). Gaseous PAH were collected on tubes filled with the adsorbent XAD-2 (SKC,

Table 1. Characteristics of the study population stratified by job category. $(A M=$ arithmetic mean, $S D=$ standard deviation, $B M I=$ body mass index)

\begin{tabular}{|c|c|c|c|c|c|c|c|c|c|c|c|c|}
\hline \multirow[t]{2}{*}{ Group } & \multicolumn{2}{|c|}{ Age (years) } & \multicolumn{2}{|c|}{ Height (cm) } & \multicolumn{2}{|c|}{ BMI } & \multicolumn{2}{|c|}{ Current smoking } & \multicolumn{2}{|c|}{ Pack-years } & \multicolumn{2}{|c|}{ Self-reported allergy } \\
\hline & AM & SD & AM & SD & AM & SD & $\mathrm{N}$ & $\%$ & AM & SD & $\mathrm{N}$ & $\%$ \\
\hline Asphalt workers $(\mathrm{N}=140)$ & 44.6 & 9.2 & 179 & 6.0 & 27.2 & 3.6 & 35 & 25 & 10.9 & 12.0 & 34 & 23 \\
\hline Reference group $(\mathrm{N}=126)$ & 46.0 & 9.5 & 179 & 6.2 & 26.6 & 3.4 & 29 & 23 & 9.9 & 11.9 & 34 & 24 \\
\hline
\end{tabular}


Blandford Forum, Dorset, UK). Filters and tubes for the collection of particulate and gaseous PAH were mounted in series during the sampling. The sampling flow rate was $2 \mathrm{l} / \mathrm{min}$. The filter and adsorbent were extracted by the addition of dichloromethane mixed with internal standards [naphthalene-D8, phenanthrene-D10, fluoranthene-D10, benzo(a)pyrene-D12].

The particle mass was measured by a microbalance (Metler Toledo AT261, Columbus, OH, USA), with a detection limit of $0.031 \mathrm{mg} / \mathrm{m}^{3}$ based on 8-hour sampling. Total PAH (16 EPA) were measured by gas chromatography with a mass selective detector. The detection limits of the PAH were $0.005-0.010 \mu \mathrm{g} / \mathrm{m}^{3}$, depending on the specific component, based on 8-hour sampling at a flow rate of 2 1/min.

Oil mist was collected on glass fiber filters (Whatman), and oil vapor was collected on tubes containing XAD-2 (SKC). Filters and tubes for the collection of oil mist and oil vapor were mounted in series during the sampling. The sampling flow rate was $2 \mathrm{l} / \mathrm{min}$. Oil mist was measured with a Fourier transform (FT-IR) spectrophotometer (PE-1600, Perkin-Elmer, MA, USA) and oil vapor was measured by chromatography with a flame ionization detector. The detection limit was $10 \mu \mathrm{g}$ and 5 $\mu \mathrm{g}$ for the oil mist and oil vapor, respectively.

Respirable dust was collected on $37-\mathrm{mm}$ cellulose acetate filters with a pore size of $0.8 \mu \mathrm{m}$ using a cyclone separator (SKC) at a sampling flow rate of $2.2 \mathrm{l} / \mathrm{min}$. The particle mass was measured gravimetrically (with a detection limit of $0.03 \mathrm{mg}$ ), and the alpha-quartz content in the respirable dust sample was measured with the FT-IR PE-1600 spectrophotometer. The detection limit was $1.7 \mu \mathrm{g} / \mathrm{m}^{3}$ if it is assumed that the sampling volume was $1 \mathrm{~m}^{3}$.

The carbon monoxide and nitrogen dioxide concentrations were measured with direct-reading electrochemical sensors with a data-logging facility built into the instrument (type PAC III, Dräger Aktiengesellscaft, Lübeck, Germany). An averaging period of one reading every 2 minutes was selected. The detection limit of the carbon monoxide and nitrogen dioxide measurements was $2 \mathrm{ppm}$ and $0.2 \mathrm{ppm}$, respectively.

\section{Assessment of respiratory health effects}

Spirometric tests. The lung function tests were performed for both the asphalt workers and the referents between 0700 and 1000 in the morning shortly before the asphalt season started. Shortly before the asphalt season ended, the lung function tests were performed again for the asphalt workers at the same time of day. The reference group was not reexamined due to study economic constraints. The participants who reported physiciandiagnosed asthma were tested, but they were excluded from the statistical analyses. All of the participants had to be free of respiratory infections for 3 weeks prior to the testing.

Spirometric measurements were performed in the sitting position with a Spirare SPS310 spirometer (Diagnostica, Oslo, Norway), using bi-directional ultrasound transit-time measurements. The spirometer was operated by the same three trained technicians. The spirometer was controlled by a 3-liter syringe. The participant wore a nose clip. The measurements were performed in accordance with the guidelines recommended by the American Thoracic Society (18). Each person performed at least three preferably identical forced vital capacity curves (ie, within a variation of $50 \mathrm{ml}$ or a maximum of $3 \%$ ). The best independent values were selected for the statistical analysis.

The following variables were recorded: forced vital capacity (FVC), forced expiratory volume in 1 second $\left(\mathrm{FEV}_{1}\right)$, and forced expiratory flow rate of $50 \%\left(\mathrm{FEF}_{50}\right)$ of the FVC. The lung function variables were expressed in absolute values and as the percentage of the predicted value according to the reference values of the European Coal and Steel Community (19).

Questionnaire. Information on age and smoking status was obtained from a general questionnaire used in an earlier cross-sectional study (16). The questions included whether the person had allergies or had been diagnosed by a physician as having asthma. The workers answered the questionnaire before the first examination. They were classified as never smokers, former smokers, and current smokers. Former smokers were those who had stopped smoking more than 12 months earlier. For the current and former smokers, the quantitative effect of smoking was measured in pack-years. Pack-years were calculated by multiplying the duration of smoking (in years) by the average number of cigarettes smoked daily divided by 20 (table 1 ).

A questionnaire was also distributed at the point of follow up. The asphalt workers were asked about job tasks they had had during the season and were divided into groups according to the tasks they had most often executed. The job tasks were asphalt plant operator, asphalt truck driver, paver operator, screedman, roller driver, and asphalt stripper.

\section{Assessment of inflammatory responses}

Blood samples were taken for the analysis of interleukin-6 (IL-6), fibrinogen, C-reactive protein (micro-CRP), and cholesterol (total and high-density lipoprotein). The workers had been told not to smoke, drink, or eat after midnight before the examination. The blood samples were taken between 0700 and 1000 in the morning shortly before the asphalt season started. Shortly before the asphalt season ended, new blood samples were taken 
at the same time of day. The blood plasma samples, anticoagulated with citrate, ethylenediaminetetraacetic acid (EDTA), and heparin, respectively, were kept on ice until 60 minutes before they were centrifuged at $2000 \mathrm{~g}$ for 15 minutes. The blood serum samples were kept at room temperature for coagulation from 60-120 minutes before they were centrifuged at $1300 \mathrm{~g}$ for 15 minutes. Plasma and serum were then frozen in cryotubes on dry ice and transported to the Ulleval University Hospital, where they were stored at $-70^{\circ} \mathrm{C}$.

EDTA plasma samples were analyzed for the concentration of IL-6 2 months after the asphalt season ended. The before- and after-season samples were analyzed at the same time at the Centre for Clinical Research, Ulleval University Hospital of Oslo, Norway. The IL-6 was measured with the commercial enzyme-linked immunosorbent assay (ELISA) kit Quantikine HS from R \& D systems, Abingdon, UK. The sensitivity of the assay is $0.039 \mathrm{pg} / \mathrm{ml}$. The other blood analyses were performed at the Department of Clinical Chemistry at the Ulleval University Hospital. The fibrinogen concentration in citrate plasma was measured according to Clauss (20) using reagents from bio Mericux (Durham, NC, USA) as adapted to their Stago analyzer. High-sensitivity micro-CRP was determined by an immunoturbidometric method (Roche, Basel, Switzerland) using a Hitachi 917 analyzer (Roche). The sensitivity of the assay is $0.03 \mathrm{mg} / \mathrm{ml}$.

\section{Data analysis}

With the use of cumulative probability plots, the exposure data were found to be best described by log-normal distributions and were ln-transformed before further statistical analyses were undertaken. The measured exposure values were used without further adjustment as they were regarded as representative of the whole workshift. Standard measures of central tendency and distributions [arithmetic (AM) and geometric (GM) means and geometric standard deviations (GSD)] were calculated. Kruskal-Wallis tests were used to evaluate the differences in the exposure levels between the job task categories. Mann-Whitney tests were used for twogroup comparisons for total dust and total PAH and IL-6. The relationship between job category and the changes in IL-6, fibrinogen, and micro-CRP was tested with a one-way analysis of variance (ANOVA).

The lung function variables were presented as percentages of the predicted values. The relationship between the lung function variables and the covariates occupational group, smoking status (pack-years), and body mass index (BMI) was investigated with an ANOVA.

The change in lung function among the asphalt workers over the asphalt season (change in FVC, change in $\mathrm{FEV}_{1}$, and change in $\mathrm{FEF}_{50}$ ), was defined as the difference between lung function at the start of the asphalt season and the lung function at the end of the season. Individual lung function changes were evaluated by comparing the lung function before and at the end of the period using paired t-tests. The relationship between the changes in lung function and job task category was tested using a one-way ANOVA with Bonferroni posthoc tests. Potential confounders (age, height, smoking status, and allergy) were evaluated for their effect using a multiple linear regression.

The statistical analyses were carried out in SPSS (version 13.0, SPSS Inc, Chicago, IL, USA).

\section{Results}

\section{Exposure}

A total of 42 asphalt workers carried personal samplers in the exposure study, and most of the workers (90\%) were monitored on more than one occasion.

The asphalt strippers had a significantly higher exposure to total dust than the other asphalt workers $(\mathrm{P}<0.001)$ (table 2). The paver operators, screedmen, and roller drivers had a significantly higher exposure to total PAH than the truck drivers, asphalt strippers, and plant operators (table 2).

Table 2. Personal exposure levels for each job category by agent (PAH = polycyclic aromatic hydrocarbons, $\mathrm{N}=$ number of measurements, $\mathrm{GM}=$ geometric mean, $\mathrm{GSD}=$ geometric standard deviation, NM=not measured)

\begin{tabular}{|c|c|c|c|c|c|c|c|c|c|}
\hline \multirow[t]{2}{*}{ Job task } & \multicolumn{3}{|c|}{ Total dust $\left(\mathrm{mg} / \mathrm{m}^{3}\right)$} & \multicolumn{3}{|c|}{ Total PAH $\left(\mu \mathrm{g} / \mathrm{m}^{3}\right)$} & \multicolumn{3}{|c|}{ Oil mist $\left(\mathrm{mg} / \mathrm{m}^{3}\right)$} \\
\hline & $\mathrm{N}$ & GM & GSD & $\mathrm{N}$ & GM & GSD & $\mathrm{N}$ & GM & GSD \\
\hline Paver operator & 16 & 0.3 & 1.9 & 12 & $1.8^{\mathrm{a}}$ & 1.9 & 7 & 0.23 & 3.4 \\
\hline Screedman & 32 & 0.3 & 2.5 & 29 & $1.6^{a}$ & 2.2 & 9 & 0.09 & 2.3 \\
\hline Roller driver & 8 & 0.4 & 2.7 & 7 & $1.3^{\mathrm{a}}$ & 4.3 & & NM & \\
\hline Asphalt stripper & 9 & $2.4^{b}$ & 1.5 & 9 & 0.5 & 1.8 & 4 & 0.19 & 2.6 \\
\hline Plant operator & 9 & 0.9 & 1.8 & 12 & 0.5 & 1.7 & & NM & \\
\hline Lorry driver & 10 & 0.1 & 2.4 & 6 & 0.3 & 1.4 & & NM & \\
\hline
\end{tabular}

a Paver operators, screedmen, and roller drivers versus other workers, Mann-Whitney test, $\mathrm{P}<0.001$; see the text for details.

${ }^{\mathrm{b}}$ Asphalt strippers versus other workers, Mann-Whitney test, $\mathrm{P}<0.001$; see the text for details. 
Although the geometric mean exposure to nitrogen dioxide was less than $1 \mathrm{ppm}$ for all of the groups, the paving group may have been exposed to higher levels when paving asphalt in tunnels (maximum $3.4 \mathrm{ppm}$ measured). Although the geometric mean exposure to oil mist was $<0.3 \mathrm{mg} / \mathrm{m}^{3}$, the exposure to oil mist can also be significant on some occasions. Oil mist was measured on one occasion as $1.7 \mathrm{mg} / \mathrm{m}^{3}$ in an asphalt paving machine without a cabin. Exposure to oil mist correlated with the exposure to total PAH (Spearman's rho $0.62, \mathrm{P}=0.04$ ).

Only a few analyses of respirable dust, volatile organic compounds, and carbon monoxide were done, due to previous analyses that showed low concentrations.

\section{Clinical and laboratory findings at the start of the season}

The asphalt workers and the reference group were comparable with respect to age, height, BMI, smoking habits, and the occurrence of self-reported allergy (table 1). Eight $(7.5 \%)$ of the asphalt workers and nine $(5.7 \%)$ of the reference group reported physician-diagnosed asthma.

$\mathrm{FEV}_{1}$ and $\mathrm{FEF}_{50}$ were significantly lower among the asphalt workers than in the reference group (table 3). There appeared to be no statistically significant dif-

Table 3. Mean (SE) lung function of the asphalt workers and a reference group before the asphalt paving season (SE = standard error of the mean, FVC = forced vital capacity, $\mathrm{FEV}_{1}=$ forced expiratory volume in 1 second, $\mathrm{FEF}_{50}=$ forced expired flow of $50 \%$ of FVC)

\begin{tabular}{|c|c|c|c|c|c|c|}
\hline \multirow[t]{2}{*}{ Group } & \multicolumn{2}{|c|}{$\begin{array}{c}\text { FVC } \\
(\% \text { of } \\
\text { predicted })\end{array}$} & \multicolumn{2}{|c|}{$\begin{array}{c}\mathrm{FEV}_{1} \\
\text { (\% of } \\
\text { predicted) }\end{array}$} & \multicolumn{2}{|c|}{$\begin{array}{c}\mathrm{FEF}_{50} \\
(\% \text { of } \\
\text { predicted) }\end{array}$} \\
\hline & Mean & SE & Mean & $\mathrm{SE}$ & Mean & SE \\
\hline Asphalt workers ( $\mathrm{N}=140)$ & 97.4 & 1.0 & $92.6^{\mathrm{a}}$ & 1.1 & $84.8^{b}$ & 2.6 \\
\hline Reference group $(\mathrm{N}=126)$ & 100.4 & 1.1 & 96.9 & 1.2 & 92.9 & 3.3 \\
\hline
\end{tabular}

a $P=0.01$

${ }^{\mathrm{b}} \mathrm{P}=0.03$, with adjustment for pack-years and body mass index. ferences in FVC between the asphalt workers and the referents, even though the asphalt workers tended to have lower lung function parameters. The lung function decline did not correlate with the duration of employment in asphalt work.

Within the asphalt worker group, the roller drivers had a statistically significant lower FVC and $\mathrm{FEV}_{1}$ than the rest of the group [FVC (\% of predicted) 92.2 (SE 2.9) versus 98.9 (SE 1.2), $\mathrm{P}=0.048$, and $\mathrm{FEV}_{1}$ (\% of predicted) 89.1 (SE 2.3) versus 95.0 (SE 1.3), $\mathrm{P}=0.04$ ]. Eight of the twelve roller drivers were former screedmen.

The results of the IL-6 measurements are shown in table 4. According to their exposure, the asphalt workers were divided into two groups, one comprised of the asphalt pavers $(\mathrm{N}=81)$ and the other forming a control group of asphalt plant operators and asphalt truck drivers $(\mathrm{N}=54)$. There were no statistically significant differences between the asphalt worker groups with respect to the before-season values. For the entire study group, the smokers had statistically significant higher IL-6 values than the nonsmokers before the season began [GM 2.11 (GSD 1.89) ng/l versus GM 1.39 (GSD 2.06) ng/l, $\mathrm{P}=0.026]$.

\section{Clinical and laboratory findings at the end of the season}

Eight asphalt workers were lost to the follow-up, three of whom were deer hunting during the follow-up period and five of whom had left the job. In addition, eight asphalt workers used asthma medicine and were excluded from the analyses, leaving 124 to be followed up.

The results of the lung function changes among the asphalt workers are shown in table 5. For the entire follow-up group, the mean values of the $\mathrm{FVC}, \mathrm{FEV}_{1}$, and $\mathrm{FEF}_{50}$ at the start of the survey were $98 \%, 94 \%$, and $87 \%$ of the predicted values, respectively. There were no statistically significant differences between the job task groups with respect to the before-season values. The screedmen had a statistically significant decrease in $\mathrm{FVC}$ and $\mathrm{FEV}_{1}$ after a season of asphalt work when compared with all of the other asphalt workers $(\mathrm{P}<0.05)$.

Table 4. interleukin-6 (II-6), fibrinogen, and C-reactive protein (micro-CRP) of the asphalt pavers and a control group of plant operators and truck drivers and changes after the asphalt season. ( $\mathrm{N}=$ number of measurements, $\mathrm{GM}=$ geometric mean, GSD = geometric standard deviation)

\begin{tabular}{|c|c|c|c|c|c|c|c|c|c|c|c|c|}
\hline \multirow[t]{2}{*}{ Job task } & \multicolumn{2}{|c|}{$\begin{array}{l}\text { IL-6 ng/l } \\
\text { before season }\end{array}$} & \multicolumn{2}{|c|}{$\begin{array}{l}\text { Change in } \\
\text { IL-6 ng/l }\end{array}$} & \multicolumn{2}{|c|}{$\begin{array}{l}\text { Fibrinogen } \\
\text { before season }\end{array}$} & \multicolumn{2}{|c|}{$\begin{array}{l}\text { Change in } \\
\text { Fibrinogen }\end{array}$} & \multicolumn{2}{|c|}{$\begin{array}{c}\text { Micro-CRP } \\
\text { before season }\end{array}$} & \multicolumn{2}{|c|}{$\begin{array}{l}\text { Change in } \\
\text { Micro-CRP }\end{array}$} \\
\hline & GM & GSD & GM & GSD & GM & GSD & $\mathrm{GM}$ & GSD & $\mathrm{GM}$ & GSD & GM & GSD \\
\hline Asphalt pavers ( $\mathrm{N}=76)$ & 1.55 & 2.0 & $1.12^{\mathrm{a}}$ & 1.75 & 3.29 & 1.2 & -0.04 & 0.4 & 0.90 & 2.5 & 0.12 & 2.1 \\
\hline Plant operators and truck drivers $(\mathrm{N}=48)$ & 1.76 & 2.1 & -0.89 & 1.91 & 3.32 & 1.2 & -0.06 & 0.6 & 1.32 & 2.4 & -0.29 & 0.9 \\
\hline
\end{tabular}

a Analysis of variance, $P=0.04$, adjusted for daily smoking during the season. 
Table 5. Lung function of the asphalt workers of each job task category and the lung function changes after the asphalt season. (FVC = forced vital capacity, $\mathrm{FEV}_{1}=$ forced expiratory volume in one second, $\mathrm{FEF}_{50}=$ forced expired flow of $50 \%$ of FVC)

\begin{tabular}{|c|c|c|c|c|c|c|c|c|c|c|c|c|}
\hline \multirow[t]{2}{*}{ Job task } & \multicolumn{2}{|c|}{$\begin{array}{c}\text { FVC (I) } \\
\text { before season }\end{array}$} & \multicolumn{2}{|c|}{$\begin{array}{l}\text { Change in } \\
\text { FVC (I) }\end{array}$} & \multicolumn{2}{|c|}{$\begin{array}{c}\mathrm{FEV}_{1}(\mathrm{I}) \\
\text { before season }\end{array}$} & \multicolumn{2}{|c|}{$\begin{array}{l}\text { Change in } \\
\mathrm{FEV}_{1}(\mathrm{I})\end{array}$} & \multicolumn{2}{|c|}{$\begin{array}{c}\mathrm{FEF}_{50}(\mathrm{l} / \mathrm{s}) \\
\text { before season }\end{array}$} & \multicolumn{2}{|c|}{$\begin{array}{l}\text { Change in } \\
\mathrm{FEF}_{50}(\mathrm{I} / \mathrm{s})\end{array}$} \\
\hline & AM & $\mathrm{SD}$ & AM & SD & AM & SD & AM & SD & AM & SD & AM & SD \\
\hline Paver operator $(\mathrm{N}=16)$ & 4.9 & 0.5 & -0.05 & 0.3 & 3.9 & 0.5 & -0.04 & 0.2 & 4.9 & 1.9 & -0.13 & 0.7 \\
\hline Screedman $(\mathrm{N}=42)$ & 4.8 & 0.8 & $0.13^{\mathrm{a}}$ & 0.4 & 3.7 & 0.6 & $0.09_{a, b}$ & 0.3 & 4.6 & 1.5 & 0.34 & 1.3 \\
\hline Roller driver $(\mathrm{N}=12)$ & 4.3 & 0.7 & -0.05 & 0.3 & 3.4 & 0.4 & 0.04 & 0.1 & 4.4 & 1.4 & 0.28 & 0.6 \\
\hline Asphalt stripper $(\mathrm{N}=6)$ & 4.9 & 1.4 & -0.21 & 0.3 & 3.9 & 1.5 & 0.04 & 0.2 & 4.9 & 2.7 & 0.87 & 1.1 \\
\hline Plant operator $(\mathrm{N}=30)$ & 4.6 & 0.8 & 0.01 & 0.3 & 3.5 & 0.6 & 0.02 & 0.2 & 4.2 & 1.6 & 0.21 & 0.8 \\
\hline Lorry driver $(\mathrm{N}=18)$ & 4.5 & 0.8 & 0.10 & 0.3 & 3.5 & 0.6 & 0.04 & 0.2 & 4.2 & 1.5 & -0.11 & 1.2 \\
\hline
\end{tabular}

a Paired sample t-test, $P<0.05$.

${ }^{\mathrm{b}}$ ANOVA, $\mathrm{P}<0.05$, screedmen versus all other asphalt workers, adjusted for smoking.

There were no significant differences between the other job task groups (table 5).

Among the screedmen the nonsmokers showed an average decrease in $\mathrm{FEV}_{1}$ of $51 \mathrm{ml}$ versus the smokers, who had a decrease of $146 \mathrm{ml}$ during the asphalt season. The difference between the nonsmokers and smokers was not significant.

The asphalt pavers had a statistically significant increase in IL-6 during the asphalt season when they were compared with the asphalt plant operators and truck drivers after adjustment for current smoking (table 4).

Only nonsmokers showed a significant increase in IL-6 during the asphalt season [change in IL-6 1.18 (GSD 1.76) ng/l]. The increase in IL-6 was not associated with a decrease in lung function. The plasma fibrinogen and serum micro-CRP levels did not increase significantly among the workers over the season, but were correlated with the increase in the IL-6 levels [Spearman's rho $0.47(\mathrm{P}=0.0001)$ for micro-CRP and $0.42(\mathrm{P}=0.001)$ for fibrinogen].

\section{Discussion}

The group of asphalt workers in this study had a significantly lower $\mathrm{FEV}_{1}$ (\% of predicted) and $\mathrm{FEF}_{50}(\%$ of predicted) than the reference group at the start of the asphalt season. The FVC and $\mathrm{FEV}_{1}$ of the screedmen decreased an average of $2.7 \%$ and $2.4 \%$, respectively, during the asphalt season. This result supports the suggestion from other studies $(6,7,16)$ that asphalt paving work may be a contributing factor to the development of obstructive lung diseases. Accelerated loss of lung function may be linked to the risk of developing lung disease, including chronic obstructive pulmonary disease (21). There is also an association between a rapid rate of decline in lung function and coronary heart disease (22). Our findings provide new evidence that employment in modern asphalt paving may lead to a decrease in lung function among screedmen during the asphalt paving season.
It is not clear, however, which agent(s) cause the observed lung function changes because the exposure of the paving team, also that of the screedmen, was low to moderate as compared with that of the Norwegian occupational exposure limits (6-48\% of the limits for total dust). There was a significant difference in the exposure to total PAH between the asphalt paving team (screedmen, paver operators and roller drivers) and the other asphalt workers (truck drivers and asphalt plant operators). The personal measurements of the total PAH exposure of the study participants showed, however, low levels when compared with the occupational exposure limits. Oil mist was only measured among the screedmen, paver operators, and asphalt strippers, but its level correlated with that of total PAH. Oil mist was the only exposure that, in one situation, was measured above the occupational exposure limit, and otherwise one-fourth of the measurements showed levels above one-third of the occupational exposure limit. The method employed to measure oil mist, 37-mm, closed-faced, three-part Millipore cassettes, has some limitations. The Millipore cassettes are known to somewhat overestimate the coarse fraction (aerodynamic diameter $>20 \mu \mathrm{m}$ ) of the thoracic fraction. However, for sampling the thoracic fraction of particles, Millipore cassettes are efficient, even though some coarse particles not belonging to the thoracic fraction are also sampled (23). Oil mist has been reported to cause airway obstruction (24).

The exposure of the screedmen did not differ from that of the rest of the asphalt paving team for total dust and total PAH. For oil mist we did not carry out sufficient measurements to determine whether or not the exposure differed. Screedmen's work is known to be physically demanding, and increased respiration (time volume), inhaling more air pollutants per time unit, may be a possible explanation for these findings. The paver operators and the roller drivers were seated within a cabin during almost all of the paving operations. The company we studied was one of few that provided cabins on paving machines and rollers for their operators. This 
use may offer another explanation for the difference in lung function between the screedmen and the machine operators.

The asphalt strippers had significantly higher exposure to total dust than the rest of the asphalt workers. We found that the strippers had a nonsignificant fall in $\mathrm{FEV}_{1}$ through the season. However, there were only six asphalt strippers, and we cannot draw any specific conclusions from this finding. Of the six, five were nonsmokers.

Smoking is an important factor in the development of airway obstruction, and the screedmen who smoked showed a greater decrease in $\mathrm{FEV}_{1}(146 \mathrm{ml})$ during the asphalt season of 6 months than the screedmen who did not smoke $(51 \mathrm{ml})$. The annual decrease determined for an unexposed nonsmoker has been estimated to be $27 \mathrm{ml}$ (25). Smokers have been shown to have an excess yearly decrease of $10 \mathrm{ml}$ (26). The excess decline that occurred among the nonsmoking screedmen was probably related to work exposure. The much accelerated decline that occurred among the smoking screedmen showed that smoking combined with the screedmen's exposure is especially problematic. With rapid rates of annual decline in $\mathrm{FEV}_{1}$, some degree of respiratory impairment could occur within 10 to 15 years.

The decline of $90 \mathrm{ml}$ in $\mathrm{FEV}_{1}$ in the group of screedmen during the asphalt season was one-third of the decrease found in a study of tunnel workers $(270 \mathrm{ml})$ after 2 weeks of exposure to nitrogen dioxide and dust from blasting (14). Among the tunnel workers, the lung function values had returned to the baseline levels for $\mathrm{FVC}, \mathrm{FEV}_{1}$, and $\mathrm{FEF}_{25-75}$ after 10 days off work. This may also be the situation for the screedmen. Asphalt workers from this company usually change worktasks, doing snow removal during the winter season, and have very little harmful exposure during the winter. However, the fact that we found reduced lung function among the asphalt workers at the start of the asphalt season may mean that repeated exposures in asphalt work may make lung function loss chronic.

An increase in IL-6 occurred among the asphalt pavers during the season, and this change may have been due to exposure in asphalt paving work. IL-6 is a proinflammatory mediator produced locally in the lung, but it may also be produced in muscle and increase during exercise $(27,28)$.

The observed relationship between exposure in asphalt work and airway dysfunction may have been biased by several factors. People who choose to enter dusty professions have better lung function than those who do not (primary health selection). To evade bias from healthy worker selection, we chose a reference group that was comparable with the study group in respect to education, socioeconomic status, and selection for employment. Thus, if primary health selection had occurred, it would have occurred in both the study and reference groups. Therefore, we believe that the observed differences in airflow limitation between the asphalt workers and the reference group may reflect differences in occupational exposure.

A drawback of the study design was, of course, that the reference group was only examined once due to study constraints; the asphalt workers were examined both before and after the asphalt season. The reference group was, as the asphalt worker group, spread all over Norway. It was decided that the expense of seeking out the reference group for another spirometric test was too high.

The lower lung function among the asphalt workers at the start of the season did not correlate with the duration of employment in asphalt work. We think, however, that the cross-sectional design of the study before the asphalt paving season may have led to an underestimation of the effects of exposure because sensitive employees may have left the occupation or changed tasks within the occupation. The workforce studied in this crosssectional survey can therefore be regarded as the "survivors" of the trade. The fact that the roller drivers had the lowest FVC and $\mathrm{FEV}_{1}$ points in this direction. Eight of the twelve roller drivers were former screedmen. Screedmen and paver operators often rake the asphalt or do hand paving, which may be physically very demanding. Working as a roller driver is less demanding.

The exposure levels measured in the personal sampling in our study highly agreed with the estimates made in previous studies of asphalt workers $(5,26)$. Oil mist, however, which may be a major problem in asphalt paving, has seldom been measured or mentioned in previous studies. In our study, exposure to oil mist was only measured among the pavers. The oil mist values correlated, however, with the exposure to total $\mathrm{PAH}$, which was significantly higher among the pavers than among the controls. More should be done to reduce exposure in asphalt paving. Possible technological solutions to reduce exposure are dependent on more exact knowledge of which agent(s) cause the lung function decline. On the basis of our results, we suspect oil mist and are planning to measure oil mist in different phases of asphalt paving during the coming asphalt season. We also want to investigate the workers' exposure to ultrafine particles. Epidemiologic studies have shown a strong association between ultrafine particles in air pollution and adverse pulmonary and cardiovascular health effects (28). Ultrafine particles have also been reported to induce an increase in inflammatory mediators, among them IL-6, in alveolar macrophage-epithelial cell cultures (30).

In conclusion, exposure during asphalt paving may enhance the risk of lung function decline among screedmen. This finding suggests that technological solutions are necessary to reduce exposure during asphalt paving. 


\section{Acknowledgments}

The authors thank the workers of Mesta for participating in the study. We thank head of the Department of Occupational Medicine, Ulleval University Hospital, Finn Levy, for his helpful comments and Monika Fosse, Ulla Irgens, Theresa Mai, and Trude Aspelin for their technical assistance.

The project received financial support from the Research Fund of Statoil, Norway.

\section{References}

1. Leonardi GS, Houthujis D, Steerenberg PA, Fletcher T, Armstrong B, Antova T, et al. Immune biomarkers in relation to exposure to particulate matter: a cross-sectional survey in 17 cities of Central Europe. Inhal Toxicol. 2000;12 suppl 4:1-14.

2. Peters A, Frolich M, Doring A, Immervoll T, Wichmann HE, Hutchinson WL, et al. Particulate air pollution is associated with an acute phase response in men; results from the MONICA-Augsburg study. Eur Heart J. 2001;22:1198-204.

3. Frampton MW, Boscia J, Roberts JR Jr, Azadniv M, Torres A, Cox C, et al. Nitrogen dioxide exposure: effects on airways and blood cells. Am J Physiol Mol Physiol. 282:L155-L165.

4. Van Eeden SF, Yeung A, Quinlam K, Hogg JC. Systemic response to ambient particulate matter: relevance to chronic obstructive pulmonary disease. Proc Am Thoracic Soc. 2005;2:61-7.

5. Burstyn I, Randem B, Lien JE, Langård S, Kromhout H. Bitumen, polycyclic aromatic hydrocarbons and vehicle exhaust: exposure levels and controls among Norwegian asphalt workers. Ann Occup Hyg. 2002;46:79-87.

6. Hansen ES. Mortality of mastic asphalt workers. Scand J Work Environ Health. 1991;17:20-4.

7. Boffetta P, Burstyn I, Partanen T, Kromhout H, Svane O, Langård S, et al. IARC epidemiological study of cancer mortality among European asphalt workers: final report. Lyon: International Agency for Research on Cancer (IARC); 2001.

8. Norseth T, Waage J, Dale I. Acute effects and exposure to organic compounds in road maintenance workers exposed to asphalt. Am J Ind Med. 1991;20:737-44.

9. Kim JY, Chen JC, Boyce PD, Christiani DC. Exposure to welding fumes is associated with acute systemic inflammatory responses. Occup Environ Med. 2005;62:157-63.

10. Burgess JL, Nanson CJ, Bolstad-Johnson DM, Gerkin R, Hysong TA, Lantz RC, et al. Adverse respiratory effects following overhaul in firefighters. J Occup Environ Med. 2001;43:467-73.

11. Burgess JL, Fierro MA, Lantz RC, Hysong TA, Fleming JE, Gerkin R, et al. Longitudinal decline in lung function: evaluation of interleukin-10 genetic polymorphism in firefighters. J Occup Environ Med. 2004;45:1013-22.

12. Backe E, Lotz G, Tittelbach U, Plitzo S, Gierke E, Schneider WD. Immunological biomarkers in salt miners exposed to salt dust diesel exhaust and nitrogen oxides. Int Arch Occup Environ Health. 2004;77:319-27.

13. Ulvestad B, Lund MB, Bakke B, Djupesland PG, Kongerud
$\mathrm{J}$, Boe J. Gas and dust exposure in underground construction is associated with signs of airway inflammation. Eur Respir J. 2001;17:416-21.

14. Bakke B, Ulvestad B, Stewart P, Lund MB, Eduard W. Effects of blasting fumes on exposure and short-term lung function changes in tunnel construction workers. Scand J Work Environ Health. 2001;27(4):250-7.

15. Hilt B, Quenild T, Holme J, Svendsen K, Ulvestad B. Increase in interleukin- 6 and fibrinogen after exposure to dust in tunnel construction workers. Occup Environ Med. 2002;59:9-12.

16. Randem BG, Ulvestad B, Burstyn I, Kongerud J. Respiratory symptoms and airflow limitation in asphalt workers. Occup Environ Med. 2004;61:367-9.

17. Frolich M, Sund M, Lowel H, Imhof A, Hoffmeister A, KoenigW. Independent association of various smoking characteristics with markers of systemic inflammation in men: results from a representative sample of the general population (MONICA Augsburg survey 1994/95). Eur Heart J. 2003;24:1365-72.

18. American Thoracic Society. Standardization of spirometry1987 update. Am Rev Respir Dis. 1987;136:1285-98.

19. Quanjar PH, Tammeling GJ, Cotes JE. Standardized lung function testing. Eur Respir J. 1993;10:1683-93.

20. Clauss A.Gerinnerungsphysiologische schnellmetode zur bestimmung des fibrinogens [Fast method for determining the level of fibrinogen]. Acta Haematol. 1957;17:237-46.

21. Burchfiel CM, Marcus EB, Sharp DS, Enright PL, Rodrigues $\mathrm{BL}$, Masaki $\mathrm{KH}$, et al. Characteristics associated with rapid declines in forced expiratory volumes. Ann Epidemiol. 1996;6:217-27.

22. Tockman MS, Pearson JD, Fleg JL, Metter JL, Kao SY, Rampal KG, et al. Rapid decline in FEV1: a new risk factor for coronary heart disease mortality. Am J Resp Crit Care. $1995 ; 151: 390-8$.

23. Vincent J. Aerosol science for industrial hygienists. Amsterdam: Elsevier Science Ltd; 1995. Chapter 9.

24. Robertson AS, Weir DC, Sherwood Burge P. Occupational asthma due to oil mists. Thorax. 1988;43:200-5.

25. Burrows B, Lebowitz MD, Camili AE, Knudson RJ. Longitudinal changes in forced expiratory volume in one second in adults: methodologic considerations and findings in healthy nonsmokers. Am Rev Respir Dis. 1986;133:974-80.

26. Marine WM, Gurr D, Jacobsen M. Clinically important respiratory effects of dust exposure and smoking in British coalminers. Am Rev Respir Dis. 1988;137:106-12.

27. Steensberg A, van Hall G, Osada T, Sacchetti M, Saltin B, Klarlund Pedersen B. Production of interleukin- 6 in contracting human skeletal muscles can account for the exercise-induced increase in plasma interleukin-6. J Physiol 2000;529:237-42.

28. Pedersen BK. Exercise and cytokines. Immunol Cell Biol. 2000;78:532-5.

29. Atkinson RW, Bremner SA, Anderson HR, Strachan DP, Bland JM, deLeon AP. Short-term associations between emergency hospital admissions for respiratory and cardiovascular disease and outdoor air pollution in London. Arch Environ Health. 1999;54:398-411.

30. Ishii H, Hayashi S, Hogg JC, Fujii T, Goto Y, Sakamoto N, et al. Alveloar magrophage-epithelial cell interaction following exposure to atmospheric particles induces the release of mediators involved in monocyte mobilization and recruitment. Respir Res. 2005;6:87.

Received for publication: 28 April 2006 